\title{
Predicting Retirement Preparation Based on Proactivity, Time Discounting and Theory of Planned Behaviour (TPB)
}

Logananthiny Kumaraguru, Caroline Geetha

To Link this Article: http://dx.doi.org/10.6007/IJARBSS/v11-i9/11237

DOI:10.6007/IJARBSS/v11-i9/11237

Received: 09 July 2021, Revised: 11 August 2021, Accepted: 28 August 2021

Published Online: 16 September 2021

In-Text Citation: (Kumaraguru \& Geetha, 2021)

To Cite this Article: Kumaraguru, L., \& Geetha, C. (2021). Predicting Retirement Preparation Based on Proactivity, Time Discounting and Theory of Planned Behaviour (TPB). International Journal of Academic Research in Business and Social Sciences, 11(9), 1660-1680.

\section{Copyright: @ 2021 The Author(s)}

Published by Human Resource Management Academic Research Society (www.hrmars.com)

This article is published under the Creative Commons Attribution (CC BY 4.0) license. Anyone may reproduce, distribute, translate and create derivative works of this article (for both commercial and non-commercial purposes), subject to full attribution to the original publication and authors. The full terms of this license may be seen at: http://creativecommons.org/licences/by/4.0/legalcode

Vol. 11, No. 9, 2021, Pg. 1660 - 1680

Full Terms \& Conditions of access and use can be found at http://hrmars.com/index.php/pages/detail/publication-ethics 


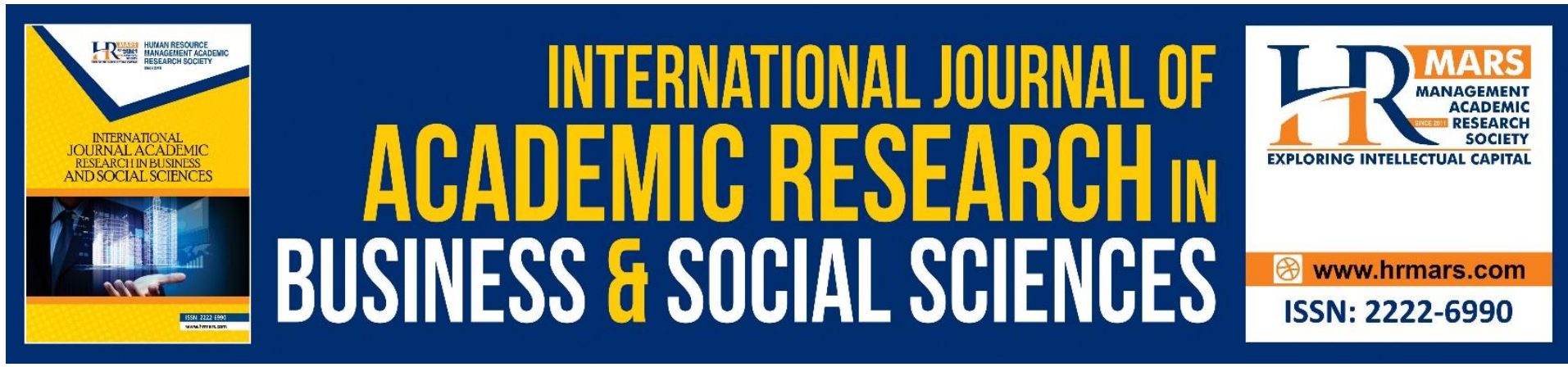

\title{
Predicting Retirement Preparation Based on Proactivity, Time Discounting and Theory of Planned Behaviour (TPB)
}

\author{
Logananthiny Kumaraguru, Caroline Geetha \\ Faculty of Business, Economics and Accountancy, Universiti Malaysia Sabah \\ Email: nanthiny90@yahoo.com
}

\begin{abstract}
Preparing for retirement is the key to a comfortable retirement. The purpose of this study is to analyze the factors that determine the retirement preparation of Gen $Y$ in Selangor, Malaysia. A model was developed and tested from an extension of the theory of planned behavior, which included individual differences in proactivity and time discounting in retirement preparation. The study uses the TPB as its main overarching theory, along with the life cycle hypothesis and prospect theory to construct its exploratory conceptual framework. A convenience sample of Gen $Y$ aged 24 to 41 is used for this study. The study collected data via an online survey and a total of 384 responses were collected. The structural equation model predicts that attitudes, perceived behavior control, proactive and time discounting positively predict preparation for retirement, whereas subjective norms do not correlate positively. The result of this study will encourage Gen $Y$ and others to prepare towards retirement to maintain a standard of living upon retirement. Future researchers, the government, insurance industries, and investment firms will benefit from this research by gaining a better understanding of influencing factors on the preparation for retirement.
\end{abstract}

Keywords: Retirement, Proactive, Time Discounting, Theory of Planned Behavior, Gen Y

\section{Introduction}

Recent developments in the finance industry indicate that managing your finances should be a skill that everyone should learn. People have difficulty making financial decisions due to the availability of various financial products and services on the financial market. Mahdzan and Tabiani (2013) claimed that the ease of access to credit cards and technological advancements in financial services leads to a lack of trust and confusion in consumers' decisions and investments. According to Han, Ko, and Choe (2019), found that most people believe that planning for post-retirement life is essential, especially in terms of finances. Planning is probably one of the most important aspects of preparing for retirement. When it comes to retirement planning, the most prevalent way to measure it is by how much people save.

Numerous studies have shown that many people do not save enough money during their working life (Antolin, 2010; Banks \& Blundell, 2005). Furthermore, several studies (Sabri \& Juen, 2014; Samad \& Mansor, 2013; Sharma, 2012; Yusuf, 2012) supported that similar 
problems also exist in Malaysia. According to Nielson (2013), the results of the survey determined that Malaysians lack confidence in facing retirement for five main reasons included loss of physical capability, struggling to meet basic needs, losing self-reliance, being a burden to family and friends and insufficient money for a comfortable life.

Malaysia has two main retirement funds. If a government employee selects a pension fund, the employee will receive pension funds monthly which will be deducted from her/his salary during the retirement period. Moreover, pension benefits are received by government employees who have attained 60 years (compulsory retirement), or men and women at the age of 50 and 45, respectively (optional retirement), or those who were medically certified as unfit for work due to diseases or accidents. According to recent statistics, the annual pension obligations or entitlements for KWAP members have tripled in the last decade to RM21.77 billion in 2017, representing an increase of $11.6 \%$ per year (Chua, 2017). Additionally, Malaysia's newly elected government has also stated that the national debt currently stands at RM1 trillion or $80 \%$ of GDP (Shukry \& Jamrisko, 2018). As a result, concerns have been raised regarding the government or taxpayers ability to continue shouldering the growing burden of pension payments while it has a high national debt (Nga \& Yeoh, 2018).

Apart from that, employees and their employers in the private sector are required to contribute to a defined contribution scheme, such as the Employee Provident Fund (EPF). The EPF is a federal statutory body formed following the Laws of Malaysia, Employees Provident Fund Act 1991 (Act 452) to safeguard compulsory retirement savings for private sector employees. The EPF contribution amount is calculated based on the monthly salary of an employee. In January 2018, employees with annual basic salaries above RM5,000 are required to contribute $11 \%$ to their employees' contributions and employers $12 \%$ (Employees Provident Fund, 2017). On the other hand, private sector employees also can select either 8 or 11 percent to be contributed to their EPF savings from their monthly salary according to the Malaysia Budget 2016. The monthly EPF contribution amounts are invested for income generation in approved financial instruments such as Loans and Bonds, Equity and Property, Malaysian Government Securities, and Money Market Instruments. An employee who contributes to EPF is eligible to withdraw from the second account for pre-retirement (Hassan, Othman \& Din, 2018). The contributions are subject to withdrawals before retirement to finance a variety of approved purposes, such as further education, medical treatment, property purchase, and approved investments. Contributors can withdraw their savings in full at 55 years old, but they are permitted to continue taking dividends up to the age of 100 (Thillainathan, 2004). However, the final sum of payment to be received by an employee upon retirement depends on the retirement age, retirement scheme and job history. Nevertheless, recent statistics indicated that $68 \%$ of Malaysians have less than RM50,000 in their EPF accounts, which means they could sustain their retirement for only five years (Chin, 2015).

While the population of Baby Boomers is decreasing and Generation $\mathrm{X}$ is getting close to retirement, Generation $Y$ is likely to dominate as the largest population group with a greater life expectancy (Yip, 2009). Preparation towards retirement must start at a young age or career stage because preparing 50 years and above is too late to accumulate enough income to sustain. Therefore, this study is to investigate the factors that influence the preparation towards retirement among the Gen $\mathrm{Y}$ in Selangor, Malaysia. Malaysia's total population in 
2018 was approximately 32.4 million, and 57.81 percent of the total population are the young generation (Department of Statistics Malaysia, 2018). Selangor is the only state in Malaysia with the largest population. Based on the Department of Statistics Malaysia (2018) reported approximately 6,475,000 million people living in Selangor and 3,009,700 (46.48\%) of them are aged between 24 to 41 years old in year old. Visyalini (2018), also supported that preparation towards retirement should be exposed to people at a younger age because it would be easier for them to know how to manage and spend their wealth wisely.

This study included the financial literacy factor that was recommended by previous researchers to identify a relationship between retirement preparation and the level of financial literacy (Moorthy et al., 2013). Financial literacy has a persuasive correlation with retirement planning, which found that high education level individuals even with a low level of financial literacy, rely more on voluntary savings for retirement life (Boisclair, Lusardi \& Michaud, 2017). Koposko (2013) study claimed that lack of financial literacy is the most significant factor that causes inadequate financial scheme practices. Previous scholars (Kimiyaghalam \& Yap, 2017) found that Malaysians seem to have some basic financial knowledge, but a large chunk of the population (63\%) lacks an understanding of the concepts of bonds, stocks, and diversification of assets. Previous empirical reports that young people and young adults are still not adequately educated about the basics of finance (Anderson, Zhan, \& Scott, 1998; Mandell \& Klein, 2007). Furthermore, many studies have demonstrated that financial literacy is correlated with the decisions people make regarding wealth management, stock market holdings, retirement insurance needs (Jappelli \& Padula, 2013; Liao, Zhang \& Zhang, 2017; Lin, Hsiao \& Yeh, 2017; Van Rooij et al., 2011). However, studies concerning financial education are still rare in developing countries, where financial literacy is lacking or even absent (Niu, Zhou \& Gan, 2020). In particular, Malaysians could have difficulties planning for retirement as a result of a low level of financial literacy.

Previous researchers (Yao, Hanma \& Montalto, 2003) found that retirement planning begins with financial literacy and is followed by investment action. Preparing for retirement is a process of preparing income goals that are affected by investment action where it reflects financial security in the future (Irawan, 2018). Other than that, the study reported that $75 \%$ of Malaysian employees were either not aware of retirement and investment planning or knew very little about it and either did not prepare for retirement planning or did so very little (Zandi, Abidin \& Nien, 2017). To address the lack of preparation of retirees, the Malaysian government introduced private or voluntary retirement funds. The voluntary retirement fund is still a relatively new concept in Malaysia. The government of Malaysia introduced and promoted two new programs under the third pillar of social security as a response to EPF's inability to support the lifestyle of retirees. Among the schemes are the Malaysia Private Retirement Scheme (PRS) and 1Malaysia Retirement Savings Scheme (1MRSS) (Samad \& Mansor, 2013). For instance, Private Retirement Scheme (PRS) was a voluntary long-term investment scheme designed to help individuals accumulate savings for retirement. PRS seeks to enhance the choices available for all Malaysians, whether employed or self-employed, to voluntarily supplement their retirement savings under a well-structured and regulated environment. Whereas, 1Malaysia Retirement Savings Scheme is designed to encourage the self-employed and those without fixed monthly income to contribute voluntarily based on what they can afford (Mohd, 2015). As Zabri, Ahmad and Lian (2016) report, Malaysians are relatively unaware of PRS schemes, and even if they are aware, they are not interested in 
investing. In the same research, the attitudes of respondents towards retirement savings indicate that most are concerned about their post-retirement lives. Researchers (Ali, Ramli \& Hussain, 2017) expressed that the main challenge mentioned by PRS providers is the lack of awareness with regard to PRS in rural areas, as well as the lack of interest in saving in urban areas although they have a better understanding of the scheme. As stated by Ibrahim et al., (2012) Malaysian employees do not plan for their retirement because they take these issues for granted. Although many previous studies show the factor influencing investment for retirement in terms of the defined contribution for retirement preparation (Millar \& Devonish, 2009; Weisbenner, 2002; Morrin, Inman, Broniarczyk Nenkov \& Reute, 2012), where mostly conducted in a developed country.

Compared with developing Asian countries, Malaysia's life insurance business only contributes $2.8 \%$ of Gross Domestic Product (GDP), compared to 6.1\% in Singapore and 7.5\% in Japan (Mahdzan \& Victorian, 2013). The market for innovative retirement products designed to help mitigate longevity risks, such as annuities and longevity bonds, is relatively small in developing economies like Malaysia (Asmuni, Shahruddin \& Redzwan, 2020). Furthermore, Lai and Tan (2009) conducted a study to examine the attitudes of Malaysians towards personal financial planning. The study revealed that many employed and selfemployed personal tend to be more positive and active towards money management insurance. This is because, in the emerging economies, a lack of awareness leads them to invest in this type of insurance protection scheme. Since Malaysia is moving towards an ageing population, the factors that need an individual to prepare for retirement have to be analyzed so that policy makers, as well as financial institutions, can design appropriate financial tools to cater to the nation. Moreover, to avoid unforeseen situations in their life and being greatly impacted, it is very important for individuals to understand the importance of being insured in today's society (Zakaria et al., 2016).

Other than that, an individual's risk tolerance is directly related to the portfolio of investments that will impact his or her ability to accumulate the necessary retirement funds and to achieve other financial objectives (Chuan et al., 2012). These researchers also claimed that the majority of retirees consume all of their retirement funds after only a few years of retirement. As a result, this study revealed that risk tolerance affects a good financial plan, especially for older people in urban areas with high living costs. Previous studies (Croy, Gerrans \& Speelman, 2010) found that risk tolerance had a small effect on retirement preparation and researchers presented evidence from the developed economies. Therefore, this research examines the importance of risk tolerance in retirement preparation in a developing economy. Hershey and Mowen (2000), stated that more pre-retirees discounted the value of a postponed reward, yet the less likely they spending time preparing towards retirement. There are few empirical investigations addressing whether time discounting has an impact on retirement preparation (Griffin, Loe \& Hesketh, 2012). Thus, the broader knowledge of time discounting and risk has been revealed in this study.

Therefore, in examining the factors that influence the preparation towards retirement among Gen Y, this study attempts to refer to the Theory of Planned behavior (TPB) which rarely addresses individual differences and demographic variables. Previous researchers (Griffin, Loe \& Hesketh, 2012) demonstrated the importance of addressing individual differences in the TPB model for the influence of behavior. Additionally, life cycle hypothesis and prospect 
theory were also added in this study, in order to provide a framework for an exploratory conceptual framework that explains the preparation towards retirement. Insufficient research has to use the TPB model with individual differences to reveal the gap in the literature. Hence, this study extends the usage of TPB to the context of preparation towards retirement.

\section{Literature Review}

The overarching theoretical framework of this study is the theory of planned behavior (TPB), but it is also based on life cycle hypothesis, and prospect theory, in order to provide a framework for an exploratory conceptual framework which explains the preparation towards retirement. As a result, TPB is the most appropriate theory for understanding financial behavior since they predict and understand human behavior (Xiao, 2008) and they explain an individual's intention to perform given a specific behavior (Ajzen, 1991). As stated by Ajzen (1991), a person's behavior is influenced by attitude, subjective norms, and perceived behavioral control in TPB model. The theory of planned behavior can be applied to individual savings behavior; if the individual has a positive attitude towards savings, this will increase their willingness to adopt retirement planning, which will give them security in their retirement years. In order to examine retirement preparation from a behavioral perspective, this study illustrates how the Theory of Planning Behavior can explain the behavior of an individual towards retirement preparation. Additionally, the prospect theory in this study has been used to identify how Gen Y's decision in risky circumstances influences their retirement preparation. Moreover, using the life cycle hypothesis in this study encourages Gen $Y$ to decide early in life that consuming less than their incomes is necessary during their youth will allow them to save and accumulate retirement assets to support themselves when they retire. The life cycle hypothesis was applied to figure out whether Gen Y saves enough for living expenses, medical expenses, emergency expenses, and entertainment expenses upon retirement in order to maintain a standard of living. Since there was limited information regarding preparation towards retirement that had been developed based on the living expenses, medical expenses, emergency expenses, and entertainment expenses, this study aims to fill this gap.

According to Azjen (1991), the Theory of Planned Behavior (TPB) is a classical model for explaining or predicting human behavior. This theory explained human behavior was influenced by three types of intentions: (1) positive and negative attitudes toward the target behavior, (2) subjective norms, and (3) perceive behavioural control (Azjen,1991). Consequently, attitude is defined as a personal response reflected as either a positive or negative reflection of a specific behavior (Zulfaka \& Kassim, 2021). A person's attitude towards retirement planning plays an important role in determining their intention or readiness for retirement (Zandi et al., 2021). Based on the evidence given by Zandi et al. (2021), several research have determined that people with a positive attitude or perception of retirement are more likely to be financially prepared for retirement. Empirical evidence (Nosi et al., 2017) also confirms that attitude influences young adults' intentions to purchase financial products associated with retirement. The current study contributes to how the level of financial literacy is developed through the intention of attitudes components of TPB model of Gen Y in Selangor, Malaysia. 
According to Widjaja, Arifin and Setini (2020), the subjective norms of TPB are governed by social values that influence someone's actions. Previous researchers (Brouwer et al., 2009; Vermeulen et al., 2011) an individual's subjective norms are shaped by thoughts of significant others (such as family members, friends, colleagues, and their immediate supervisor) about their behavior. Researchers (Jamal et al., 2015; Thung et al., 2012) concluded that subjective norms originating from the environment, including friends and family as a source of influence on behavior. Many researchers have considered subjective norms such as family, friends or colleagues when it comes to retirement, whereas this research investigated subjective norms that include a moral obligation, organizational commitment and financial advisor. In accordance with the social norm hypothesis, the more social support an individual gets from friends, family, spouses, or social regulation, the more likely they are to plan for retirement savings (Duflo \& Saez, 2002). The study by Madrian and Shea (2001) reported that the choice of retirement savings of an individual is influenced by their co-workers. Previous scholars ( Wood et al., 2012) found that the decision-making position in the household influences retirement planning.

The perception of behavioral control is another important predictor of behavior in TPB. An individual's perception of perceived behavioral control greatly influences how easy or difficult it is to perform a given behavior (Lajuni et al., 2018). The perception of preparing for retirement through asset accumulation, investment actions, and insurance protection is found to affect behavioral intention via the perceived behavioral control construct. More empirical about PBC have found a positive and direct correlation between the factor and behavioral intention (AL Ziadat, 2015; Botetzagias, Dima, \& Malesios, 2015; Johnson, 2017; Nelson, 2014). Researchers (Yusof et al., 2018) indicate that individuals with a high perceived level of control are more likely to save for retirement. According to Fishbein and Ajzen (2010), the perception of behavior control can directly influence a person's actual behavior in some research, while other research shows that the relationship between these two aspects is indirect.

Previous scholars (Bateman, Stevens \& Lai, 2015) found that people's specific parameters towards risk preferences in gain and loss, loss aversion, and error propensity variability of investment choices in their retirement planning are estimated by using prospect theory. Waweru, Munyoki and Uliana (2008) described that prospect theory influenced a person's decision-making processes, including regret aversion and loss aversion. Generally, the wise investor avoids regret by trading shares when the value has declined and selling once the price has increased. Furthermore, Fogel and Berry (2006), claimed that investors tend to regret selling winning stocks too soon than holding losses for too long. People are more likely to feel pain from a loss than pleasure from equivalent gains, based on the prospect theory. In general, people under-weight probable outcomes compared with certain ones, and they respond differently to similar events depending on the context of loss or gain in which they are presented (Kahneman \& Perttunen, 2004). As stated by Runnoh and Ndirang (2018), prospect theory was utilized in their research in order to investigate the decision making between current consumption and saving for future consumption or upon job exit. In assessing whether Gen $Y$ decisions involve risk towards retirement preparation, this study applied prospect theory. 
The life cycle hypothesis was utilized to investigate Gen Y's understanding of preparation towards retirement including living expenses, medical expenses, emergency expenses and entertainment expenses. Kaur and Hassan (2018), discovered that a weak economy, high living expenses, worrying debt increase and unpredictable currency performances contribute heavily to Gen Y's savings habits and retirement planning in Malaysia. Previous researchers (Mansor et al., 2015) claimed that people who do not prepare well for retirement would need to continue working even after retirement in order to maintain living expenses. Researchers (Mahdzan, Mohd-Any \& Chan, 2017) also supported that insufficient retirement savings lead to struggles for retirees to maintain their pre-retirement income and they may face difficulties to cover living expenses. Therefore, individuals who are preparing for retirement should make sure they have sufficient savings to cover their living expenses after retirement. Hence, this life cycle hypothesis could be used to find data on whether Gen $Y$ has enough savings to maintain living expenses upon retirement.

Research on the TPB model rarely considers individual differences to influence behavior. This research includes individual differences in TPB model to identify whether proactive and time discounting influence the preparation towards retirement. In the retirement context, limited research has included individual differences in TPB to influence the behavior. This is supported by Griffin, Loe and Hesketh (2012) who made individual differences in TPB model part of their study. Hence, there is a research gap found, where limited research was conducted solely upon Gen $Y$ for the relationship between individual differences and retirement preparation. 


\section{Conceptual Framework}

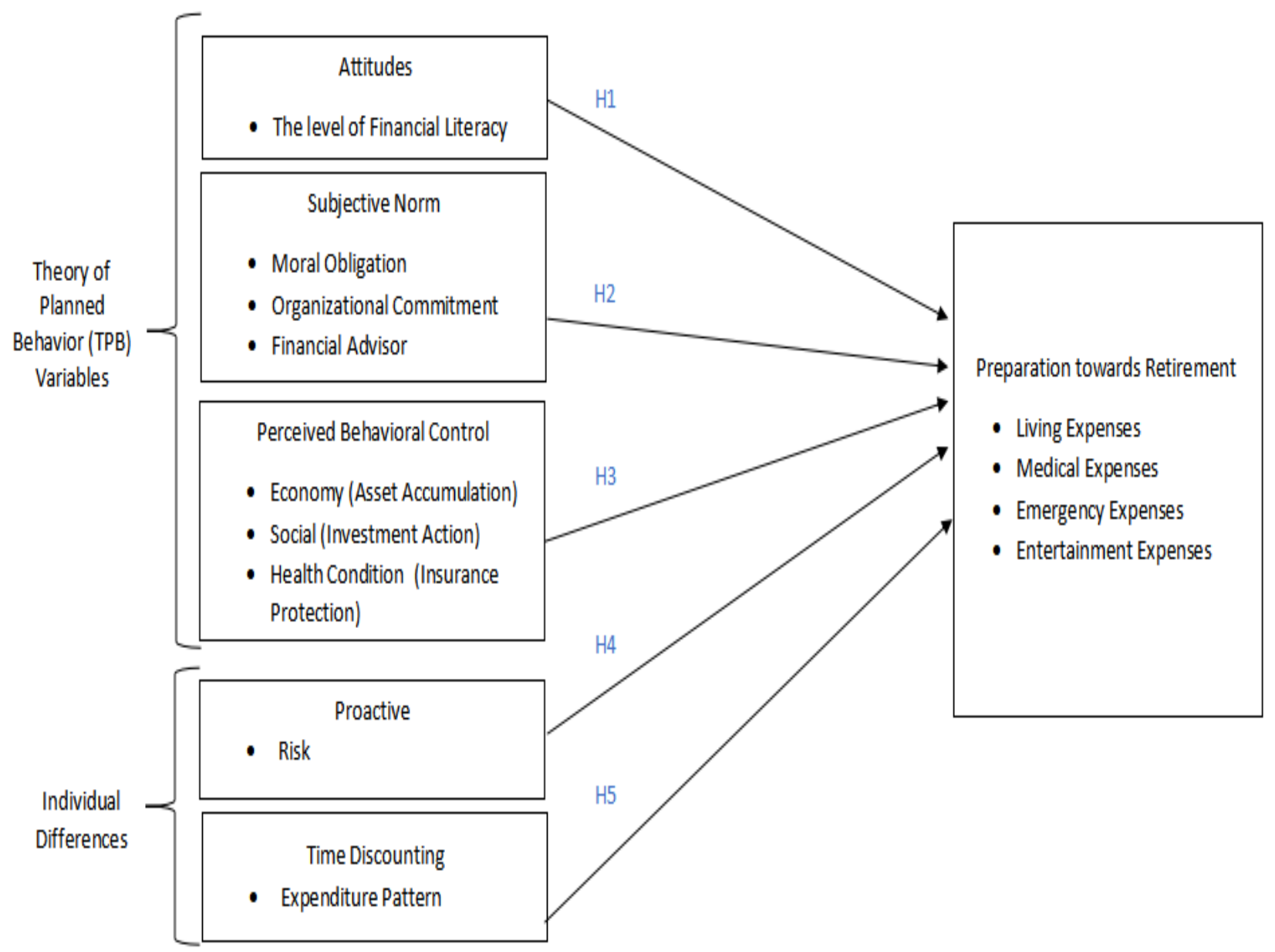

Figure 1 : Conceptual Framework

Source: Adapted and modified from Dan, (2004); Butrica, Goldwyn \& Johnson, (2005); Ibrahim, Isa and Ali (2012); Griffin, Loe, \& Hesketh, (2012); Mahdzan \& Tabiani (2013); Ibrahim \& Wahat (2015); Agunga Mourine (2017); Nga \& Yeoh (2018).

\section{Statement of Hypothesis}

The following hypothesis statements are formulated to answer the research question and objectives.

H1:

H2:

H3:

H4:

H5:
Attitudes can positively influence the preparation towards the retirement.

Subjective norms can positively influence the preparation towards the retirement.

Perceived behavioral control can positively influence the preparation towards the retirement.

Proactive can positively influence the preparation towards the retirement.

Time Discounting can positively influence the preparation towards the retirement. 


\section{Research Hypothesis \\ Attitudes (The level of Linancial Literacy)}

A process of improving knowledge and skills called financial literacy (Widjaja, Arifin \& Setini, 2020). Sanjeewa and Hongbing (2019) stated that individuals with this ability are more likely to get involved in managing their finances and learning how to appropriately meet their financial needs in the future. Previous scholars (Brown \& Graf, 2013) indicate that the level of financial literacy has a positive correlation with retirement preparation and favoring a retirement savings account. Financial literacy is positively correlated with retirement planning and the results of an empirical analysis indicate that respondents with greater confidence in their financial knowledge build plans more often (Lusardi, 1999; Lusardi \& Mitchell, 2007, 2009, 2011; Ameriks, Caplin \& Leahy, 2003). Therefore, the third hypothesis for this study is as below:

\section{H1: Attitudes can positively influence the preparation towards the retirement.}

\section{Subjective Norm (Moral Obligation, Organizational commitments and Financial Advisor)} According to (Zandi et al., 2021), subjective norms are defined as the pressures or expectations placed upon individuals by their social environment that influence their decisions to engage in certain behaviors or avoid them. Subjective norm is generally applied from family, friends, or colleagues at work to influence a person's decision and judgment (Zandi et al., 2021). This study explores subjective norms applied to moral obligation, organizational commitment and financial advisor among Gen $Y$ in Selangor. Past research has found that subjective norms is positively associated with Gen $Y$ students' intentions to invest in a retirement fund (Bongini \& Cucinelli, 2019). In a recent study from Taylor University in Malaysia, millennials who were influenced by their parents to save and invest for retirement also showed positive correlation (Alwi, Amir Hashim \& Ali, 2015). Apart from that, Thung et al. (2012) found that perceptions of retirement from others influence Malaysians' disposition to retire, including the younger generation. Furthermore, a study conducted by (Chia et al., 2011) showed that parental and peer influence will ultimately affect university students' saving behavior for retirement. Hence, the subjective norm could be hypothesized as below:

\section{H2: Subjective norm can positively influence the preparation towards the retirement}

\section{Perceived Behavioral Control}

This research extends the TPB model by investigating the influences of perceived behavioral control (asset accumulation, investment action and insurance protection) on the preparation towards retirement. As cited by Lajuni et al (2018), the concept of perceived behavioral control (PBC) was introduced to the TRA along with attitude and social norms in order to develop the theory of planned behavior (TPB). According to Ajzen (2008), perceived behavioral control (PBC) is known as a measure of the ease or difficulty of performing certain behaviors and it implies past experiences as well as anticipated obstacles and impediments. Further, Davis and Hustvedt (2012) added that individuals with high perceived behavioral controls had a successful saving experience and conclude that perceived behavioral control was found to be the most important variable predicting savings. According to Yusof, Sabri, Rahim and Jusoh (2018), stated that individuals with higher perceived control saved more for retirement. 
First, this study investigates how asset accumulation is developed through the perceived behavioral control components of TPB framework among Gen $Y$ in Selangor. Previous researchers (Brinson, Hood \& Beebower, 1986) examined that over 90 percent of the variability in portfolio returns can be explained by asset allocation such as stocks, bonds, and cash. According to Hariharan, Chapman and Domian (2000), present asset returns over long holding periods in a form useful for pre-retirement planning. Consequently, this factor can positively influence the preparation towards retirement by accumulating assets such as a house or land, which would help the aged population throughout golden years. Apart from that, Lusardi (2006) claimed that asset accumulation and retirement preparation are positively related. Hence, individuals should save while working in order to finance their consumption and income shortfalls during retirement. In order to ensure an adequate income in retirement, younger people must build up assets prior to retirement during their working life.

Secondly, this research examines how investment action formulated through the perceived behavioral control element of TPB model of Gen Y in Selangor, Malaysia. As cited by Jamaludin and Gerrans (2015), EPF invests primarily in low or middle-risk investments, so it was crucial for members to make good investment choices. Ibrahim, Isa and Ali (2012), claim that there was a positive relationship between investment action and preparation towards retirement because individual's contributions at the point of retirement may not be enough to cover living maintenance in the golden years and high possibility of running out of money within three years. Interestingly, Van Rooij, Lusardi and Alessie (2012) claimed that good investment increases stock ownership and high knowledge individuals have an opportunity to exploit the risk premium on equity investments, and doing so might contribute to the positive relationship towards retirement.

Thirdly, this research analyzes how insurance protection develops through perceived behavioral control part of TPB model influences Gen Y. Previous scholars (Rogowski \& Karoly, 2000) stated that there was a significant relationship between insurance and preparation towards retirement because insurance was an important determinant of retirement. The idea of lifetime insurance system allows a given amount of pension savings of an individual to be used for benefits under all the risks in retirement (Stiglitz \& Yun, 2005). Rogowski and Karoly (2000) found that health insurance also an important determinant of retirement preparation Thus, the fifth hypothesis for this study was:

H3: Perceived Behavioral Control can positively influence the preparation towards the retirement

\section{Individual Differences (Proactive)}

This study examined the role of personality traits in shaping proactive behavior in trying to explain such individual differences. This study investigates how proactive (risk) influences retirement preparation among Gen $Y$ in Selangor, Malaysia. According to Parker, Williams and Turner (2006), proactive behavior is defined as self-initiated and future-oriented actions aiming to change or improve situations. As cited by Balaz (2020), a general risk trait also involves a willingness to invest in risky financial assets, such as stocks or stock funds. Risk taking behavior one of an important component of financial planning and plays in shaping consumer financial decisions, where risk positively influences the preparation 
towards retirement (Grable \& Rabbani, 2014). Previous researchers (Dulebohn \& Murray, 2008) claimed that investment positively correlated with risk taking behavior that influence the retirement savings. Hence, the proactive could be hypothesized as below:

H4: Proactive can positively influence the preparation towards the retirement.

\section{Individual Differences (Time Discounting)}

This study investigates how time discounting influences the preparation towards retirement among Gen $Y$ in Selangor, Malaysia. Therefore, this research supports the view that individual differences in time discounting affect people's expenditure pattern in different ways. Previous scholars (Bidewell, Griffin \& Hesketh, 2006) stated that time discounting positively influences the preparation towards retirement. Apart from that, Griffin, Loe and Hesketh (2012) conclude that the concept of time discounting, which includes in studies preparation towards retirement positively influences individuals to plan their expenditure pattern where they want to invest or save on capital expenditure or spend on consumer expenditure such as household goods and services. Thus, time discounting is hypothesized as below:

\section{H5: Time discounting can positively influence the preparation towards the retirement}

\section{Data and Method}

\section{Research Paradigm and Design}

A positivist paradigm was used in this study since it attempts to objectively examine the factors that influence retirement preparation among Gen $Y$ through procedures and approaches that are reproducible. Eddie (2012) stated that most research on social science tends to fall into experimental (positivism) with a more ontology philosophy in which the experts think there is a real world and they have empiricist epistemology where they believe that they need multiple data points to determine it. In this research, as ontologically the researcher believes that a single tangible reality exists that can be understood, identified and measured. Epistemologically the researchers believe that knowledge can and should be developed objectively, without relying on the personal values of the researchers or participants. Methodologically the researchers believe that positivism emphasizes engaging in research in settings where variables can be manipulated and controlled.

In this study, quantitative data is collected in the form of a survey to assess the relationship between factors that influence the preparation towards retirement with a structured selfadministrated questionnaire as a means for collecting data. This study will employ a quantitative approach, using a descriptive design to summarize the results. According to Babbie and Mouton (2002), data collection for quantitative research is driven by structured data collection techniques, and the data collected must be expressed numerically. In quantitative research, numerical information is collected in a systematic manner often through controlled conditions and then analyzed (Polit \& Hungler, 1996).

According to Avedian (2014), surveys are used to collect information from a sample of entities so that they can produce quantitative descriptors of the characteristics of the larger population of which the entities are members. A survey is a way for researchers to collect data on trends, attitudes, or opinions of a population by studying a sample of that population and it can consist of a cross-sectional and longitudinal study using questionnaires or 
structured interviews for data collection with the intent to generalize the findings (Creswell \& Creswell, 2018). Therefore, this study investigated the relationship between several factors that influence retirement preparation by gathering quantitative data through a survey instrument.

\section{Target Population}

The target population for this study is Gen Y or the Millennium cohort those who are aged between 24 to 41 years old from Selangor, Malaysia. Ting, Lim, de Run, Koh and Sahdan (2018) reported that Gen Y or Millennium generation refers to those who were born between 1977 and 1994 and this cohort will be the engine of growth over the next two decades. Moreover, people who are between 24 to 41 years old are also grouped under the career stage. According to Krejicie and Morgan (1970) as cited by Sekaran (2003), a sample size of 384 Gen $\mathrm{Y}$ (for the populations of 3,009,700 Gen Y) is acceptable to conduct a research. Thus, 384 respondents were chosen as the target population for this research study.

\section{Sampling Procedure}

This study applied the convenience sampling method. The questionnaires were distributed to the respondents and each respondent took 10 to 15 minutes to answer the questionnaires. Generally, a mail survey response rate of more than $40 \%$ is considered good (Cohen, Manion $\&$ Morrison, 2007). Furthermore, to overcome the possibility of non-response problem, a total 800 sets of questionnaires were distributed to all respondents with the assumption that $50 \%$ of the response rate is good enough for researchers to continue this study. Thus, 800 questionnaire sets had been distributed via online surveys among Gen $Y$ in this study.

\section{Results}

\section{Profile of Respondents}

The total of 384 respondents profile was tabulated based on the demographic profile and background of the respondents based on the detail in the questionnaires. The analysis of the respondents' information reveals that the majority of the respondents were female $(55.5 \%)$ and the rest were male (44.5\%). There are 37.5 percentage of respondents who come in groups of ' 30 to 35 years' old. Apart from that, 36.7 percent of respondents are belong to the range of ' 24 to 29 years' old. The remaining 25.8 percent comes from the category of ' 36 to 41 years' old.

Moreover, 47.4 percent were Indians, 27.3 percent were Malays, 19.5 percent were Chinese, 4.9 percent were Bumiputra and the remaining 0.8 percent represented other races. In terms of academic qualification, about 36.2 percent of respondents were Degree/BA/BS holders, 28.6 percent were MA/MS/MBA holders, 19.8 percent were Diploma/Higher Diploma holders, 6 percent were Professional Degree holders, 4.7 percent were PhD holders, 2.6 percent were PMR/O-Level/SPM holders and the smallest percentage which was 2.1 percent came from the category of A-level/STPM holders.

In terms of income, the highest personal income was 38.8 percent of the respondents whose earnings belong to category 'RM2001-RM4000' monthly. There were 26.8 percent of respondents who earned between 'RM4001-RM6000' monthly, 19.3 percent respondents earned 'under RM2000' monthly, 8.3 percent of respondents earned between 'RM6001RM8000', while only 6.8 percent of respondents reported an income 'over RM8000' monthly. 
Apart from that 44.5 percent were working more than five years, 27.9 percent respondents worked between 2 to 5 years, 14.6 percent respondents worked between 1 to 2 years years, and the remaining 13.3 percent worked less than a year.

In terms of marital status, about 50.8 percent of the respondents were single, 47.7 percent of respondents were married and the remaining 1.6 percent represented those who were divorced. Table 4.1 showed that 2 people depended financially on 30.7 percent of respondents, 0 people depended financially on 25.3 percent of respondents, 3 people depended financially on 15.4 percent of respondents, 1 people depended financially on 14.6 percent of respondents and more than 4 people depended financially on 14.1 percent of respondents.

\section{Convergent Validity}

Convergent validity is assessed by the average variance extracted (AVE) for all items associated with each construct which is proposed by Fornell and Larcker (1981). An acceptable AVE is 0.50 or higher, as it indicates that on average, the construct explains over 50 percent of the variance of its items. AVE is calculated by dividing the total factor loading power of two by the number of items in the sample (Urbach \& Ahlemann, 2010).The greater the composite reliability, the more reliable it is. In exploratory research, composite reliability values of 0.600 to 0.700 are acceptable, whereas values of 0.700 to 0.900 can be considered as satisfactory in more advanced stages of research (Nunnally \& Bernstein,1994). According to the results of this study reported all indicators found good composite reliability values which range from 0.851 (Time Discounting) to 0.958 (Preparation towards retirement).

\section{Discriminant Validity}

According to Hair, Sarstedt, Pieper and Ringle (2012), stated the square root of each constructed AVE should be higher than its higher correlation with other constructs. Table 4.2 shows that the square roots of the AVE value correspond to non-bolded values indicating the extent to which the constructs are inter-correlated.

Table 4.2: Discriminant Validity Fornell \& Larker (1981)

\begin{tabular}{llllllll}
\hline & Construct & 1 & 2 & 3 & 4 & 5 & 6 \\
\hline 1 & ID-Proactive & $\mathbf{0 . 7 9 9}$ & & & & & \\
2 & ID-Time discounting & 0.632 & $\mathbf{0 . 7 6 8}$ & & & & \\
3 & Pre_Retirement & 0.670 & 0.736 & $\mathbf{0 . 7 4 8}$ & & & \\
4 & TPB-Attitudes & 0.521 & 0.607 & 0.691 & $\mathbf{0 . 7 2 2}$ & & \\
5 & TPB-P.B.Control & 0.680 & 0.737 & 0.834 & 0.695 & $\mathbf{0 . 7 0 7}$ & \\
6 & TPB-Subjective & 0.662 & 0.573 & 0.665 & 0.540 & 0.714 & $\mathbf{0 . 7 6 0}$ \\
\hline
\end{tabular}

Note: Diagonals represent the square root of the AVE while the off diagonals represent the correlations

\section{Coefficient of Determination $\left(\mathbf{R}^{2}\right)$}

The $R^{2}$ value obtained from PLS is the value that indicates the amount of variance in dependable variable that is explained by independent variables. The larger the $R^{2}$ value, the 
higher the predictability ability of a structural model. In addition, by using SmartPLS Algorithm, $R^{2}$ value can be obtained for the t-statistic value from the 5000 resample bootstrapping. According to Chin (1998), R2 values of around 0.670 are substantial, values around 0.333 average, and values of 0.190 and lower weak. Therefore, the $R^{2}$ value of this research is 0.754 and acceptable.

\section{Hypothesis Testing}

The result revealed significant relationship for $H 1(\beta=0.165, t=3.952, p=0), H 3(\beta=0.450$, $t=7.434, p=0), H 4(\beta=0.104, t=2.425, p=0.016)$ and $H 5(\beta=0.193, t=3.386, p=0.001)$. This result indicates an insignificant relationship for $\mathrm{H} 2(\beta=-0.073, t=1.697, p=0.090)$. Given that, hypotheses $\mathrm{H} 1, \mathrm{H} 3, \mathrm{H} 4$ and $\mathrm{H} 5$ are supported, whereas $\mathrm{H} 2$ are not supported.

\section{Conclusion}

The research study was carried out to have a better understanding of the factors that influence the preparation towards retirement among Gen $Y$ in Selangor, Malaysia. The overall objective of this study is to identify the factors that influence preparation for retirement. The dependent variable of the study was preparation towards retirement while the independent variables were theory of planned behavior (attitudes, subjective norms, perceived behavioral control) and individual differences (proactive and time discounting). The finding indicated that hypotheses $\mathrm{H} 1, \mathrm{H} 3, \mathrm{H} 4$ and $\mathrm{H} 5$ are supported. Therefore, this study suggests that the level of financial literacy has an interaction towards retirement preparation among Gen Y.This study suggests that individuals with basic knowledge of savings, interest rates, inflation rates, stocks, unit trusts, retirement schemes, percentage calculation, and investment tend to be prepared towards retirement. Next, this study suggests that Gen $Y$ believes that asset accumulation has interaction preparation towards retirement. This study suggests that individuals who have high asset accumulation tend to have a comfortable retirement.this study suggests that the investment action has interaction towards retirement preparation among Gen Y. This study also suggests that Gen Y prefers to invest in unit trusts, real estate, bonds, shares and retirement schemes to prepare for their retirement.Furthermore, this study suggests that insurance protection has interaction with retirement preparation among Gen Y. This study suggests that purchasing life insurance will provide financial support to covers health or critical illness, personal accidents or unforeseen circumstances. Apart from that, these findings suggest that proactive have interaction towards retirement preparation among Gen Y. This study suggests that people with proactive behavior are more likely to be good financial planners and able to make decisions on investment and asset accumulation for retirement preparation. Moreover, these findings suggest that time discounting has an interaction with retirement preparation among Gen $\mathrm{Y}$. This study suggests that time discounting leads Gen $Y$ to plan their expenditures for capital, household, insurance and investment in order to save for retirement. However, $\mathrm{H} 2$ are not supported. This study revealed that moral obligation, organizational commitment and financial advisor are not influencing the preparation towards retirement among Gen Y. This research was useful for the young generation to realize the importance of retirement in life and the factors that influence the preparation towards retirement. This study would help readers to identify the suitable time and right marketing techniques to prepare for their retirement. This research will also be useful for the Malaysian government to recognize the current situation in order to help the young generation in developing a better environment after retirement. In 
summary, this research had achieved the objective which is to examine the factors that influence the preparation towards retirement.

\section{References}

Abd Samad, S., \& Mansor, N. (2017). Population ageing and social protection in Malaysia. Malaysian Journal of Economic Studies, 50 (2), 139-156.

Mourine, A. (2017). Financial Literacy and Financial Preparedness for Retirement among Permanent and Pensionable Employees in State Owned Corporations in Nairobi, Kenya. International Journal of Business and Social Science, 8 (11).

Ajzen, I. (1991). The theory of planned behavior. Organizational behavior and human decision processes, $50(2), 179-211$.

Ajzen, I. (2008). "TPB bibliography". Retrieved from www.people.umass.edu/aizen/TPBrefs.html on 4 March 2020.

AL Ziadat, M. T. (2015). Applications of Planned Behavior Theory (TPB) in Jordanian Tourism. International Journal of Marketing Studies, 7(3), 95-106.

Ali, A. N. M., Ramli, A. L. Y., \& Hussain, M. A. (2017). Private Retirement Scheme as a Financial Protection of Old-Age in Malaysia from the Perspective of PRS Providers. International Journal of Innovation and Business Strategy (IJIBS), 7(1), 18-25.

Alwi, S., Hashim, A. I., \& Ali, S. M. (2015). Factors Affecting Savings Habits within Millennials in Malaysia. In: Fourth Asia Pacific Conference on Global Business Economics.

Ameriks, J., Caplin, A., \& Leahy, J. (2003). Wealth accumulation and the propensity to plan. The Quarterly Journal of Economics, 118 (3), 1007-1047.

Anderson, K. H., Burkhauser, R. V., \& Quinn, J. F. (1986). Do Retirement Dreams Come True? The Effect of Unanticipated Events on Retirement Plans. Ind. Labor Relat. Rev., 39 (4), 518-26.

Antolin, P. (2010). Private pensions and the financial crisis: How to ensure adequate retirement income from DC pension plans. OECD Journal: Financial Market Trends, 2009 (2), 153-179.

Asmuni, N. H., Shahruddin, S. N. S. S. M., \& Redzwan, N. (2020). Value for Money of Retirement Insurance Plans in Malaysia with Consideration of Longevity Factor.

Avedian, A. (2014). Survey design. Harvard Law School. Retrieved from hnmcp.law.harvard.edu_Arevik-Avedian-Survey-Design-PowerPoint on 4 February 2020.

Babbie, E., \& Mouton, J. (2001). The practice of social research: South African edition. Cape Town: Oxford University Press Southern Africa.

Balaz, V. (2020). Risk Taking, Experience, and Retirement Savings. Economic and Social Development: Book of Proceedings, 1-12.

Banks, J., \& Blundell, R. (2005). Private pension arrangements and retirement in Britain. Fiscal Studies, 26 (1), 35-53.

Bateman, H., Stevens, R., \& Lai, A. (2015). Risk information and retirement investment choice mistakes under prospect theory. Journal of behavioral finance, 16 (4), 279-296.

Bidewell , J. , Griffin , B. , \& Hesketh , B. (2006). Timing of retirement: Including a delay discounting perspective in retirement models. Journal of Vocational Behavior, 68 (2), $368-387$.

Boisclair, D., Lusardi, A., \& Michaud, P. C. (2017). Financial literacy and retirement planning in Canada. Journal of Pension Economics \& Finance, 16 (3), 277- 296. 
Bongini, P., \& Cucinelli, D. (2019). University students and retirement planning: never too early. International Journal of Bank Marketing, 37 (3), 775-797.

Botetzagias, I., Dima, A. F., \& Malesios, C. (2015). Extending the Theory of Planned Behavior in the context of recycling: The role of moral norms and of demographic predictors. Resources, Conservation and Recycling, 95 , 58- 67.

Brinson, G. P., Hood, L. R., \& Beebower, G. L. (1986). Determinants of portfolio performance. Financial Analysts Journal, 42 (4), 39-44.

Brouwer, S., B. Krol, M. F. Reneman, U. Bultmann, R. L. Franche, J. J. L. van der Klink and J. W. Groothoff. (2009). Behavioral determinants as predictors of return to work after longterm sickness absence: An application of the theory planned behavior. Journal of Occupational Rehabilitation 19 (2), 166174.

Brown, M., \& Graf, R. (2013). Financial literacy and retirement planning in Switzerland. Numeracy, 6 (2), 6.

Butrica, B. A., Goldwyn, J. H., \& Johnson, R. W. (2005). Understanding expenditure patterns in retirement.

Chia, Y. K., Chai, M. T., Fong, S. N., Lew, W. C., \& Tan, C. T. (2011). Determinants of saving behaviour among the university students in Malaysia (Doctoral dissertation, UTAR).

Chin, C. (2015). Too poor to retire. The Star Online. Retrieved from http://www.thestar.com.my/news/nation/2015/04/19/too-poor-to-

retireconcerned- that-analarmingly-high number-of-54yearold-malaysians-havelessthan-r/ on 8 August 2020.

Chua, S. (2017). Cover story: The pension time bomb. The Edge Weekly. Retrieved from http://www.theedgemarkets.com/article/cover-story-pension-timebomb on 6 May 2020.

Chuan, C. S., Wan, C. W., Kai, S. B., \& Kok, N. K. (2012). Perception of financial risk tolerance of older urban Chinese in Malaysia. International Journal of Academic Research, 4 (3).

Cohen, L., Manion, L., \& Morrison, K. (2007). Observation. Research methods in education, 6, 396-412.

Creswell, J. W., \& Creswell, J. D. (2018). Research design: Qualitative, quantitative and mixed approach(5th ed). Los Angeles: SAGE publication, Inc.

Croy, G., Gerrans, P., \& Speelman, C. (2010). Injunctive social norms primacy over descriptive social norms in retirement savings decisions. The International Journal of Aging and Human Development, 71 (4), 259-282.

Davis, K., \& Hustvedt, G. (2012). It'sa matter of control: Saving for retirement. International Review of Social Sciences and Humanities, 3 (2), 248-261.

Duflo, E., \& Saez, E. (2002). Participation and investment decisions in a retirement plan: The influence of colleagues' choices. Journal of public Economics, 85 (1), 121-148.

Dulebohn, J. H., \& Murray, B. (2008). Understanding risk taking in retirement savings through attitude. Financial Services for the Greater Good, 1-13.

Eddie, C. (2012). What are ontology and epistemology?. Retrieved from http://eddiechauncy.blogspot.my/2012/01/what-are-ontology-andepistemology_ 12.html. on 5 January 2020.

Fishbein, M., \& Ajzen, I. (2010). Predicting and changing behavior: The reasoned action approach. New York: Taylor \& Francis Group.

Fogel, O., \& Berry, T. (2006). The disposition effect and individual investor decisions: the roles of regret and counterfactual alternatives. Journal of Behavioral Finance, 7 (2),107116. 
Fornell, C., \& Larcker, D. F. (1981). Evaluating structural equation models with unobservable variables and measurement error. Journal of Marketing Research, 18 (1), 39-50.

Grable, J. E., \& Rabbani, A. (2014). Risk tolerance across life domains: Evidence from a sample of older adults. Journal of Financial Counseling and Planning, 25(2), 174.

Griffin, B., Loe, D., \& Hesketh, B. (2012). Using proactivity, time discounting, and the theory of planned behavior to identify predictors of retirement planning. Educational Gerontology, 38 (12),877-889.

Hair, J. F., Jr., Ringle, C. M., \& Sarstedt, M. (2012). Partial least squares: The better approach to structural equation modeling? Long Range Planning, 45 (5/6), 312- 319.

Han, J., Ko, D., \& Choe, H. (2019). Classifying Retirement Preparation Planners and Doers: A Multi-Country Study. Sustainability, 11 (10), 2815.

Hariharan, G., Chapman, K. S., \& Domian, D. L. (2000). Risk tolerance and asset allocation for investors nearing retirement. Financial Services Review, 9 (2), 159-170.

Hassan, S., Othman, Z., \& Din, W. Z. W. (2018). Does the Employees Provident Fund Provide Adequate Retirement Incomes to Employees?. Asian Journal of Economics, Business and Accounting, 1-11.

Hershey, D. A., \& Mowen, J. C. (2000). Psychological determinants of financial preparedness for retirement. The Gerontologist, 40 (6), 687-697.

Ibrahim, D. K. A., \& Wahat, N. W. A. (2015). A new pathway towards retirement preparation: Integration of holistic life planning. European Journal of Social Science Education and Research, 2 (4), 154-160.

Ibrahim, D., Isa, Z. M., \& Ali, N. (2012). Malaysian Savings Behavior towards retirement planning. In Proceedings of 2012 International Conference on Economics Marketing and Management.

Irawan, A. N. C. (2018). Determinant of Investment Choice for Retirement Planning in Indonesia (Doctoral Dissertation, President University).

Jamaludin, N., \& Gerrans, P. (2015). Retirement savings investment decisions: Evidence from Malaysia. Journal of the Asia Pacific Economy, 20 (4), 644- 657.

Jappelli, T., Padula, M. (2013). Investment in financial literacy and saving decisions. J. Bank. Financ. 37 (8), 2779-2792.

Johnson, D. P. (2017). How Attitude Toward the Behavior, Subjective Norm, and Perceived Behavioral Control Affects Information Security Behavior Intention. Walden University. Retrieved from http://scholarworks.waldenu.edu/dissertations on 3 June 2020.

Kahneman, D., \& Perttunen, J. (2004). Holding onto the losers: finish evidence. The Journal of Behavioral Finance, 5 (2), 116-126.

Kaur, B., \& Hassan, Z. (2018). Impact of age, gender, income, education and financial literacy towards retirement planning among generation'Y'in Malaysia. International Journal of Education, Learning and Training, 3 (1).

Kimiyaghalam, F., \& Yap, S. (2017). Level of financial literacy in Malaysia. International Journal of Research, 4 (7), 1065-1074.

Koposko, J. L. (2013). Parental and social influences on understanding of financial planning for retirement. Oklahoma State University.

Krejicie, R. V., \& Morgan, D. W. (1970). Determining sample size for research activities. Educational and Psychological Measurement, 30, 607-610. 
Lajuni, N., Abdullah, N., Bujang, I., \& Yacob, Y. (2018). Examining the predictive power of financial literacy and theory of planned behavior on intention to change financial behavior. International Journal of Business and Management Invention, 7 (3), 60-66.

Liao, L., Zhang, X., Zhang, Y. (2017). Mutual fund managers' timing abilities. Pacific-Basin Finance Journal, 44, 80-96.

Lin, C., Hsiao, Y., Yeh, C. Y. (2017). Financial literacy, financial advisors, and information sources on demand for life insurance. Pacific-Basin Finance Journal, 43 , 218-237.

Lusardi, A. (1999). Information, expectations, and savings for retirement. Behavioral dimensions of retirement economics, 81, 115.

Lusardi, A. (2006). Financial literacy and financial education: Review and policy implications. NFI Policy Brief, (2006-PB), 11.

Lusardi, A., \& Mitchell, O. S. (2007). Baby boomer retirement security: The roles of planning, financial literacy, and housing wealth. Journal of monetary Economics, 54 (1),205- 224.

Lusardi, A., \& Mitchell, O. S. (2011). Financial literacy around the world: an overview. Journal of pension economics \& finance, 10 (4),497-508.

Madrian, B., \& Dennis, S. (2001). Preaching to the Converted and Converting Those Taught: Financial Education in the Workplace. University of Chicago Working Paper.

Mahdzan, N. S., \& Tabiani, S. (2013). The impact of financial literacy on individual saving: An exploratory study in the Malaysian context. Transformations in Business \& Economics, 12 (1), 41-55.

Mahdzan, N. S., \& Victorian, S. M. P. (2013). The determinants of life insurance demand: A focus on saving motives and financial literacy. Asian Socia Science, 9 (5), 274.

Mahdzan, N. S., Mohd-Any, A. A., \& Chan, M. K. (2017). The influence of financial literacy, risk aversion and expectations on retirement planning and portfolio allocation in Malaysia. Gadjah Mada International Journal of Business, 19 (3), 267.

Mandell, L., \& Klein, L. S. (2007). Motivation and financial literacy. Financial services review, $16(2)$.

Millar, M., \& Devonish, D. (2009). Attitudes, savings choices, level of knowledge and investment preferences of employees toward pensions and retirement planning: Survey evidence from Barbados. Pensions: An International Journal, 14 (4), 299-317.

Mohd, S. (2015). Provident fund for the informal sector: a case study of the informal sector workers in Kuala Lumpur, Malaysia. Journal of Malaysian Studies, 33.

Moorthy, M. K., Durai, T., Chelliah, L., Sien, C. S., Leong, L. C., Kai, N. Z., \& Teng, W. Y. (2012). A Study on the retirement planning behaviour of working individuals in Malaysia. International Journal of Academic Research in Economics and Management Sciences, $1(2), 54$.

Morrin, M., Inman, J. J., Broniarczyk, S. M., Nenkov, G. Y., \& Reuter, J. (2012). Investing for retirement: The moderating effect of fund assortment size on the $1 / n$ heuristic. Journal of Marketing Research, 49 (4), 537-550.

Nelson, A. (2014). Using the Theory of Planned Behavior to Predict Infant Restraint Use in Saudi Arabia. Loma Linda University.

Nga, K. H., \& Yeoh, K. K. (2018). An exploratory model on retirement savings behaviour: A Malaysian study. International Journal of Business and Society, 19 (3), 637-659.

Niu, G., Zhou, Y., \& Gan, H. (2020). Financial literacy and retirement preparation in China. Pacific-Basin Finance Journal, 59, 101262. 
Nosi, C., D'Agostino, A., Pagliuca, M., \& Pratesi, C. A. (2017). Securing retirement at a young age. Exploring the intention to buy longevity annuities through an extended version of the theory of planned behavior. Sustainability, 9 (6), 1069.

Nunnally, J., \& Bernstein, I. (1994). Psychometric theory. McGraw Hill, New York.

Parker, S. K., Williams, H. M., \& Turner, N. (2006). Modeling the antecedents of proactive behavior at work. Journal of applied psychology, 91 (3), 636.

Rogowski, J., \& Karoly, L. (2000). Health insurance and retirement behavior: evidence from the health and retirement survey. Journal of Health Economics, 19 (4), 529-539.

Runnoh, J. N., \& Ndirangu, A. N. (2018). Influence of investment diversification knowledge on job exit preparedness among hospitals' employees in Nakuru town, Kenya.

Sabri, M. F., \& Juen, T. T. (2014). The influence of financial literacy, saving behaviour, and financial management on retirement confidence among women working in the Malaysian public sector. Asian Social Science, 10 (14), 4.

Samad, S. A., \& Mansor, N. (2013). Population ageing and social protection in Malaysia. Malaysian Journal of Economic Studies, 50(2), 139.

Sanjeewa, W. S., Hongbing, O., \& Hashmi, S. H. (2019). Determinants of life insurance consumption in emerging insurance markets of South-Asia. International Journal of Information, Business and Management, 11 (4), 109-129.

Sekaran, U. (2003). Research methods for business: a skill building approach. $4^{\text {th }}$ ed., John Wiley \& Sons Inc., 2003.

Sharma, S. K. (2012). Malaysia: Updating and Improving the Social Protection Index. ADBTechnical Assistance Consultant's Report.

Shukry, A., \& Jamrisko, M. (2018). Malaysia's 1 Trillion Ringgit Government Debt Explained, Retrieved from https://www.bloomberg.com/news/articles/2018-05-24/malaysia-s1-trillion-ringgit-government-debt-explained on 8 June 2020.

Stiglitz, J. E., \& Yun, J. (2005). Integration of unemployment insurance with retirement insurance. Journal of public economics, 89 (11), 2037-2067.

Thillainathan, R. (2004). Malaysia: Pension and financial market reforms and issues on governance. In Pension in Asia: incentives, compliance and their role in retirement conference, Hitosubashi University, Tokyo, 1-40. Hershey, D. A., Jacobs.

Thung, C. M., Kai, C. ing, Nie, F. S., Chiun, L. W., \& Tsen, T. C. (2012). Determinants of saving behaviour among the university students in Malaysia. Universiti Tunku Abdul Rahman, 109.

Ting, H., Lim, T. Y., de Run, E. C., Koh, H., \& Sahdan, M. (2018). Are we Baby Boomers, Gen X and Gen Y? A qualitative inquiry into generation cohorts in Malaysia. Kasetsart Journal of Social Sciences, 39 (1), 109-115.

Urbach, N., \& Ahlemann, F. (2010). Structural Equation Modeling In Information Systems Research Using Partial Least Squares. Journal Of Information Technology Theory And Application, 11 (2), 5-40.

Van Rooji, M. C., Lusardi, A., \& Alessie, R. J. (2011). Financial literacy and retirement planning in the Netherlands. Journal of Economic Psychology, 32 (4), 593-608.

Visyalini, S. (2018). Financial literacy education and retirement planning of the urban elderly in Malaysia/Visyalini Selvadurai (Doctoral dissertation, University of Malaya).

Waweru, M., Munyoki, E., \& Uliana, E. (2008). The effects of behavioral factors in investment decision-making: a survey of institutional investors operating at the Nairobi Stock Exchange. International Journal of Business and Emerging Markets, 1 (1), 24-41. 
Weisbenner, S. (2002). Do pension plans with participant investment choice teach households to hold more equity?. Journal of Pension Economics \& Finance, 1 (3), 223-248.

Widjaja, I., Arifin, A., \& Setini, M. (2020). The effects of financial literacy and subjective norms on saving behavior. Management Science Letters, 10 (15), 3635-3642.

Wood, A., Downer, K., Lees, B., \& Toberman, A. (2012). Household Financial Decision Making: Qualitative research with couples, Department for Work and Pensions Research Report 805, London: DWP.

Xiao, J. J. (2008). Applying behavior theories to financial behavior. In Xiao, J.J. (Ed.), Handbook of Consumer Finance Research (Chapter 5, 69-81). NY, NY: Springer.

Yao, R., Hanna, S. D., \& Montalto, C. P. (2003). The capital accumulation ratio as an indicator of retirement adequacy. Journal of Financial Counseling and Planning, 14 (2), 1-11.

Yip, C. (2009). Redefining Retirement Planning. Retrieved from http://biz.thestar.com.my/news/story.asp?file=/2009/10/31/business/49567 42\&sec=business Zappala on 7 July 2021.

Yusof, R., Sabri, M. F., Rahim, H. A., \& Jusoh, Z. M. (2018). Examining the Behavioural Intention to Save in a Voluntary Retirement Fund in Malaysia. Malaysian Journal Of Consumer and Family Economics VOL. 21.

Yusuf, M. M. (2012). Women and pensions in Malaysia: assessing the impacts of disruptions in working life. University of Southampton.

Zabri, S. M., Ahmad, K., \& Lian, A. A. L. H. (2016). The awareness of private retirement scheme and the retirement planning practices among private sector employees in Malaysia. International Journal of Economics and Financial Issues, 6 (6), 120-124.

Zakaria, Z., Azmi, N. M., Hassan, N. F. H. N., Salleh, W. A., Tajuddin, M. T. H. M., Sallem, N. R. M., \& Noor, J. M. M. (2016). The intention to purchase life insurance: A case study of staff in public universities. Procedia Economic and Finance, 37, 358-365.

Zandi, G. R., Abidin, S. Z., \& Nien, S. K. (2017). The Preparations of Employees Towards Retirement and Estate Planning: The case of Malaysia, International Journal of Applied Business and Economic Research, Vol.15 (22).

Zandi, G., Torabi, R., Yu, O. T., Sivalingam, A. D., \& Khong, T. T. (2021). Factors Affecting The Intention of Generation $Y$ in Malaysia to Invest for Retirement. Advances in Mathematics: Scientific Journal 10 (2021), no.3, 1485-1507.

Zulfaka, A., \& Kassim, S. (2021). Retirement Awareness Among The Working Population Below 40 In Malaysia. Journal of Islamic Finance, 10, 101-110. 